\title{
COMPOSITION AND BIOLOGICAL ACTIVITY OF THE ESSENTIAL OIL OF PERUVIAN LANTANA CAMARA
}

\author{
JULIO BENITES ${ }^{l}$, CRISTINA MOITEIRO*2, GRAÇA MIGUEL ${ }^{3}$, LEONEL ROJO $^{l}$, \\ JOSÉ LÓPEZ', FLORENCIA VENÂNCIO'2, LUISS RAMALHO', SÓNIA FEIO', \\ SUSANA DANDLEN ${ }^{3}$, HUGO CASANOVA ${ }^{4}$, AND IVÁN TORRES ${ }^{4}$
}

\author{
${ }^{I}$ Departamento de Ciencias Químicas y Farmacéuticas, Universidad Arturo Prat, Casilla 121, Iquique, Chile. \\ 2INETI, Instituto Nacional de Engenharia Tecnologia e Inovação I.P., Departamento de Tecnologia de Indústrias Químicas, \\ Estrada do Paço do Lumiar, 1649-038 Lisboa, Portugal. \\ ${ }^{3}$ Faculdade de Engenharia de Recursos Naturais, Universidade do Algarve, Campus de Gambelas, 8005-139 Faro, Portugal. \\ ${ }^{4}$ Facultad de Farmacia y Bioquímica, Universidad Privada Antonio Guillermo Urrelo, Cajamarca, Perú. \\ (Received: February 23, 2009 - Accepted: June 24, 2009)
}

\begin{abstract}
The composition of the essential oil from Lantana camara L. (Verbenaceae) obtained by hydrodistillation of the aerial parts was examined by GC, GC/ MS, and ${ }^{13} \mathrm{C}$-NMR. The GC analysis showed that carvone is the most abundant monoterpene $75.9 \%$, together with limonene $16.9 \%$, accounting for $92.8 \%$ of the oil. The major components were also tested by ${ }^{13} \mathrm{C}$-NMR analysis of the essential oil. The $L$. camara oil was assayed against several microorganisms, showing moderate antibacterial activity against the human pathogen Staphylococcus aureus (MIC $200 \mu \mathrm{g} / \mathrm{ml}$ ). High antioxidant activity evaluated by the Trolox equivalent antioxidant capacity assay (TEAC) was found $(29.0 \mathrm{mmol}$ Trolox $/ \mathrm{kg}$ ) and relative low anti-inflammatory activity due to its weak ability for inhibiting lipoxygenase $\left(\mathrm{IC}_{50}=81.5 \mu \mathrm{g} / \mathrm{ml}\right)$.
\end{abstract}

Keywords: Antibacterial, antioxidant, anti-inflammatory, carvone, ${ }^{13} \mathrm{C}-\mathrm{NMR}$, essential oil composition, GC-MS, Lantana camara, limonene, Verbenaceae.

\section{INTRODUCTION}

Lantana camara L. (Verbenaceae) is a hairy shrub native to Central and South America. This plant has been introduced in many countries as an ornamental or hedge plant, and is now a highly invasive weed in many places around the world. In Peru, L. camara (locally named as "yerba de la maestranza" and "siete colores") ${ }^{1}$ has been completely naturalized throughout the coast. Different parts of the plant are used in folk and traditional medicine systems for the treatment of health disorders including tetanus, malaria, tumors, and rheumatism, as well as also symptoms such as itches, dermatitis, ulcers, swellings, catarrh, dysentery, bilious fever, and eczema ${ }^{1-6}$.

The essential oils (EOs) derived from leaves and flowers of different colors of $L$. camara isolated by diverse methods and collected in different locations and seasons have been previously investigated, showing great variation in their chemical composition (Table 1). In general, $\beta$-caryophyllene was the sesquiterpene identified in all essential oils from different origins (6-35\%). The EOs of $L$. camara showed a wide spectrum of antibacterial and antifungal activities $^{5,7}$.

Antioxidant and (Rosas-Romero \& Saavedra, 2005) and anti-inflammatory activities $^{9-11}$ of several extracts of $L$. camara from different origins have been reported, but to the best of our knowledge this is the first report on the composition and biological activity of EO obtained from the Peruvian specimens of $L$. camara.

Here we report the analysis of EO from aerial parts of $L$. camara (yellow flowers) collected in Trujillo, Peru, and its biological activity against human pathogenic bacteria, as well as its antioxidant and anti-inflammatory activity. Our previous studies have demonstrated that Peru EO is enriched in carvone and limonene. 
J. Chil. Chem. Soc., 54, No 4 (2009)

Table 1. Main constituents of the essential oils of Lantana camara from different geographical origins previously reported

\begin{tabular}{|c|c|c|c|c|c|c|}
\hline $\begin{array}{l}\text { Retention Indices } \\
\text { Apolar }^{\mathrm{a}} \quad \text { Polar }^{\mathrm{a}}\end{array}$ & Main components & $\begin{array}{l}\text { Percentage } \\
(\%)\end{array}$ & Origin & Part of plant & Type of isolation & Reference \\
\hline $\begin{array}{l}1612 \\
1780 \\
2004\end{array}$ & $\begin{array}{l}\beta \text {-Caryophyllene } \\
\text { ar-Curcumene } \\
\text { Caryophyllene epoxide }\end{array}$ & $\begin{array}{l}13 \\
25 \\
7\end{array}$ & $\begin{array}{l}\text { Cameroon } \\
\text { (West } \\
\text { Africa) }\end{array}$ & $\begin{array}{l}\text { Leaves }+ \\
\text { flowers }\end{array}$ & Hydrodistillation & 19 \\
\hline $\begin{array}{l}1123 \\
1612 \\
1724 \\
1780 \\
2031\end{array}$ & $\begin{array}{l}\text { Sabinene } \\
\beta \text {-Caryophyllene } \\
\text { Zingiberene } \\
\text { ar-Curcumene } \\
\text { Nerolidol }\end{array}$ & $\begin{array}{l}7 \\
11 \\
19 \\
16 \\
11\end{array}$ & Cameroon & Leaves & Hydrodistillation & 19 \\
\hline $\begin{array}{l}1612 \\
1780 \\
2031\end{array}$ & $\begin{array}{l}\beta \text {-Caryophyllene } \\
\text { ar-Curcumene } \\
\text { Nerolidol }\end{array}$ & $\begin{array}{l}8 \\
27 \\
13\end{array}$ & Cameroon & Flowers & Hydrodistillation & 19 \\
\hline $\begin{array}{l}1612 \\
1724 \\
1780\end{array}$ & $\begin{array}{l}\beta \text {-Caryophyllene } \\
\text { Zingiberene } \\
\text { ar-Curcumene }\end{array}$ & $\begin{array}{l}20 \\
11 \\
27\end{array}$ & Cameroon & Leaves & $\begin{array}{l}\text { Headspace by dynamic } \\
\text { method }\end{array}$ & 19 \\
\hline $\begin{array}{l}1612 \\
2040\end{array}$ & $\begin{array}{l}\beta \text {-Caryophyllene } \\
\text { Davanone }\end{array}$ & $\begin{array}{l}12 \\
15\end{array}$ & Madagascar & $\begin{array}{l}\text { Leaves }+ \\
\text { flowers }\end{array}$ & Hydrodistillation & 19 \\
\hline $\begin{array}{l}1118 \\
1582\end{array}$ & $\begin{array}{l}\Delta^{3} \text {-Carene } \\
\beta \text {-Caryophyllene }\end{array}$ & $\begin{array}{l}10 \\
19\end{array}$ & Madagascar & Not referred & Not referred & 20 \\
\hline Not determined & $\begin{array}{l}\text { Davanone } \\
\beta \text {-Caryophyllene } \\
\text { Sabinene } \\
\text { Linalool } \\
1,8 \text {-Cineole } \\
\alpha \text {-Humulene } \\
\beta \text {-Bisabolene } \\
\text { ar-Curcumene } \\
\text { Caryophyllene oxide } \\
\gamma \text {-Cadinene }\end{array}$ & $\begin{array}{l}23-26 \\
11-14 \\
9-11 \\
5-6 \\
4-5 \\
4-5 \\
2 \\
1-2 \\
1 \\
<0.5\end{array}$ & Madagascar & $\begin{array}{l}\text { Aerial part } \\
\text { (pink-violet } \\
\text { flowers) }\end{array}$ & Steam distillation & 21 \\
\hline Not determined & $\begin{array}{l}\beta \text {-Caryophyllene } \\
\beta \text {-Bisabolene } \\
\text { Sabinene } \\
\gamma \text {-Cadinene } \\
\alpha \text {-Humulene } \\
\text { ar-Curcumene } \\
1,8 \text {-Cineole } \\
\text { Linalool } \\
\text { Davanone } \\
\text { Caryophyllene oxide }\end{array}$ & $\begin{array}{l}26-31 \\
14-15 \\
9-14 \\
1-5 \\
2-3 \\
1-3 \\
1 \\
0.4-1 \\
0-1 \\
<05\end{array}$ & Madagascar & $\begin{array}{l}\text { Aerial part } \\
\text { (yellow-orange } \\
\text { flowers) }\end{array}$ & Steam distillation & 21 \\
\hline Not determined & $\begin{array}{l}\beta \text {-Caryophyllene } \\
\text { Davanone } \\
\text { Linalool } \\
\text { 1,8-Cineole } \\
\beta \text {-Bisabolene } \\
\gamma \text {-Muurolene }\end{array}$ & $\begin{array}{l}16 \\
12 \\
5 \\
4 \\
2 \\
1\end{array}$ & Madagascar & Commercial & Not referred & 21 \\
\hline $\begin{array}{l}1427 \\
1460 \\
1487 \\
1500 \\
1550 \\
1560 \\
1577 \\
1640 \\
1643\end{array}$ & $\begin{array}{l}\beta \text {-Caryophyllene } \\
\alpha \text {-Humulene } \\
\text { Germacrene D } \\
\text { Bicyclogermacrene } \\
\text { Elemol } \\
\text { Nerolidol } \\
\text { Caryophyllene oxide } \\
\text { Cubenol } \\
\alpha \text {-Cadinol }\end{array}$ & $\begin{array}{l}21 \\
11 \\
4 \\
9 \\
3 \\
4 \\
4 \\
2 \\
2\end{array}$ & $\begin{array}{l}\text { Brazzaville } \\
\text { (Congo) }\end{array}$ & Leaves & Hydrodistillation & 22 \\
\hline $\begin{array}{r}968 \\
1020 \\
1419 \\
1451 \\
1495\end{array}$ & $\begin{array}{l}\text { Sabinene } \\
1,8 \text {-Cineole } \\
\beta \text {-Caryophyllene } \\
\alpha \text {-Humulene } \\
\delta \text {-Guayene }\end{array}$ & $\begin{array}{l}13 \\
9 \\
19 \\
10 \\
5\end{array}$ & $\begin{array}{l}\text { Republic } \\
\text { of Benin } \\
\text { (Western } \\
\text { Africa) }\end{array}$ & Leaves & Hydrodistillation & 7 \\
\hline
\end{tabular}




\begin{tabular}{|c|c|c|c|c|c|c|c|}
\hline $\begin{array}{r}974 \\
1008 \\
1028 \\
1419 \\
1480\end{array}$ & & $\begin{array}{l}\text { Sabinene } \\
\alpha \text {-Phellandrene } \\
\text { Limonene } \\
\beta \text {-Caryophyllene } \\
\text { Germacrene D }\end{array}$ & $\begin{array}{l}9 \\
16 \\
17 \\
11 \\
13\end{array}$ & $\begin{array}{l}\text { State of } \\
\text { Amapá } \\
\text { (North } \\
\text { Brazil) }\end{array}$ & $\begin{array}{l}\text { Leaves }+ \text { thin } \\
\text { branches }\end{array}$ & Hydrodistillation & 24 \\
\hline $\begin{array}{l}1453 \\
1484 \\
1500\end{array}$ & & $\begin{array}{l}\alpha \text {-Humulene } \\
\gamma \text {-Curcumene }+ \text { ar- } \\
\text { curcumene } \\
\alpha \text {-Zingiberene }\end{array}$ & $\begin{array}{l}11 \\
28 \\
19\end{array}$ & $\begin{array}{l}\text { State of } \\
\text { Pará (North } \\
\text { Brazil) }\end{array}$ & $\begin{array}{l}\text { Leaves }+ \text { thin } \\
\text { branches }\end{array}$ & Hydrodistillation & 24 \\
\hline $\begin{array}{r}982 \\
993 \\
1425 \\
1490 \\
1494 \\
1509 \\
1515 \\
1581\end{array}$ & $\begin{array}{l}1124 \\
1157 \\
1628 \\
1760 \\
1726 \\
1740 \\
1758 \\
1966\end{array}$ & $\begin{array}{l}\beta \text {-Pinene } \\
\text { Myrcene } \\
\text { trans- } \beta \text {-Caryophyllene } \\
\text { Bicyclosesquiphellandrene } \\
\alpha \text {-Zingiberene } \\
E, E-\alpha \text {-Farnesene } \\
\gamma \text {-Bisabolene } \\
\text { trans- } \beta \text {-Caryophyllene } \\
\text { oxide }\end{array}$ & $\begin{array}{l}0.2-3 \\
2-4 \\
14-15 \\
16-18 \\
\\
5-6 \\
3-4 \\
3-4 \\
4-9\end{array}$ & Colombia & $\begin{array}{l}\text { Leaves + } \\
\text { branches }\end{array}$ & $\begin{array}{l}\text { Hydrodistillation; } \\
\text { Microwaves } \\
\text { hydrodistillation; SFE; } \\
\text { Dynamic headspace } \\
\text { extraction }\end{array}$ & 25 \\
\hline $\begin{array}{r}1020 \\
975 \\
1419 \\
1450 \\
1491\end{array}$ & & $\begin{array}{l}1,8 \text {-Cineole } \\
\text { Sabinene } \\
\beta \text {-Caryophyllene } \\
\alpha \text {-Humulene } \\
\text { Bicyclogermacrene }\end{array}$ & $\begin{array}{l}10 \\
17 \\
14 \\
6 \\
8\end{array}$ & Iran & $\begin{array}{l}\text { Leaves + } \\
\text { flowers }\end{array}$ & Hydrodistillation & 25 \\
\hline $\begin{array}{l}1380 \\
1391 \\
1425 \\
1434 \\
1484 \\
1498\end{array}$ & & $\begin{array}{l}\alpha \text {-Copaene } \\
\beta \text {-Elemene } \\
\beta \text {-Caryophyllene } \\
\alpha \text {-Cadinene } \\
\text { Germacrene D } \\
\gamma \text {-Elemene }\end{array}$ & $\begin{array}{l}5 \\
7 \\
9 \\
3 \\
21 \\
10\end{array}$ & $\begin{array}{l}\text { Northern } \\
\text { India }\end{array}$ & Leaves & & 27 \\
\hline $\begin{array}{l}1380 \\
1391 \\
1425 \\
1434 \\
1484 \\
1498\end{array}$ & & $\begin{array}{l}\alpha \text {-Copaene } \\
\beta \text {-Elemene } \\
\beta \text {-Caryophyllene } \\
\alpha \text {-Cadinene } \\
\text { Germacrene D } \\
\gamma \text {-Elemene }\end{array}$ & $\begin{array}{l}11 \\
15 \\
7 \\
7 \\
11 \\
7\end{array}$ & $\begin{array}{l}\text { Northern } \\
\text { India }\end{array}$ & Flowers & & 27 \\
\hline \multirow{2}{*}{\multicolumn{2}{|c|}{$\begin{array}{l}864 \\
877 \\
901 \\
905\end{array}$}} & $\begin{array}{l}\text { Germacrene D } \\
\alpha \text {-Humulene } \\
\beta \text {-Caryophyllene } \\
\text { Germacrene B }\end{array}$ & $\begin{array}{l}16 \\
9 \\
12 \\
6\end{array}$ & South China & Aerial parts & Steam distillation & 6 \\
\hline & & $\begin{array}{l}\beta \text {-Caryophyllene }(10-30 \%) / \\
\text { sabinene }(30 \%) / \text { bisabolenes } \\
(15 \%) / \beta \text {-sesquiphellandrene } \\
(>10 \%)\end{array}$ & & Egypt & $\begin{array}{l}\text { Leaves + } \\
\text { flowers }\end{array}$ & & 28 \\
\hline
\end{tabular}

${ }^{\mathrm{a}} \mathrm{GC}$ Column 


\section{MATERIAL AND METHODS}

\section{Plant material}

L. camara plants with yellow flowers were collected in January 2007 from Trujillo at 32 m.a.l.s., in the region of La Libertad, Perú, and identified by Prof. Fredy Pelaéz from the "Herbario Truxillense de la Facultad de Ciencias Biologicas de la Universidad Nacional de Trujillo." A voucher sample under accession $\mathrm{N}^{\circ} 932$ was deposited in this herbarium.

\section{Oil essential isolation}

Air dried aerial parts, $40 \mathrm{~g}$, were subjected to hydrodistillation for $5 \mathrm{~h}$ using a Clevenger-type apparatus. The oil yield on a moisture-free basis was $4.5 \%(\mathrm{w} / \mathrm{w})$

\section{GC and GC-MS analysis}

Chromatographic analysis of the oil of $L$. camara was carried out on a Hewlett Packard 5890 series II GC equipped with an Automatic Sampler HP 6890 series injector linked to two injector modules, two flame ionization detectors and two columns, together with a computer station for data treatment. The columns were an OV-101 fused silica $(50 \mathrm{~m} \times 0.25 \mathrm{~mm}, 0.25 \mu \mathrm{m}$ film thickness) and Supelco wax 10 (30 m x $0.25 \mathrm{~mm}, 0.25 \mu \mathrm{m}$ film thickness). Oven temperature was held at $70^{\circ} \mathrm{C}$ for $5 \mathrm{~min}$ and then programmed to $220^{\circ} \mathrm{C}$ at $2{ }^{\circ} \mathrm{C} /$ min. The detector and injector were kept at $250^{\circ} \mathrm{C}$ and $240^{\circ} \mathrm{C}$, respectively. Helium was used as carrier gas, at constant pressure $55 \mathrm{kPa}$ for the OV-101 and $45 \mathrm{kPa}$ for the Supelco wax10. A $1 \mu 1$ of oil was injected. The identification of the essential oil components is given in Table 2 and was made by comparison of their retention indices (RI) obtained from calculated values relative to $\mathrm{C}_{8}-\mathrm{C}_{2}$ $n$-alkanes. The intensity of each peak was integrated. The sample was analyzed three times. The average peak areas of all GC signals were added together and the percentage of each component peak was calculated by comparing its average area to the total area.

The GC-MS analysis for identification of compounds was carried out in a Carlo Erba HRGC-MS gas chromatography equipped with a KRATOS mass detector model MS25RF (sector instrument) and a HP-5MS column (30 m x $0.25 \mathrm{~mm}, 0.25 \mu \mathrm{m}$ film thickness), carrier gas helium, constant pressure 90 $\mathrm{kPa}$, split $1: 20$. The oven was programmed initially from $70^{\circ} \mathrm{C}$ with $2 \mathrm{~min}$ hold up time to the final temperature of $250^{\circ} \mathrm{C}$ with $5^{\circ} \mathrm{C} / \mathrm{min}$ ramp. The final temperature hold time was $5 \mathrm{~min}$. The inlet and $\mathrm{GC} / \mathrm{MS}$ interface temperatures were kept at $250^{\circ} \mathrm{C}$ and $280^{\circ} \mathrm{C}$, respectively. The temperature of EI $70 \mathrm{eV}$ source was $200^{\circ} \mathrm{C}$ with full scan $(25-450 \mathrm{~m} / \mathrm{z})$, scan time $0.3 \mathrm{~s}$. The mass spectra of essential oil components were identified by comparing the mass spectra of the analytes with those of authentic standards from the mass spectra of Wiley 6.0 and Mass Spectra Library (NIST 98), and with corresponding data of components from reference oils analyzed in our laboratory.

\section{NMR Spectroscopy}

The ${ }^{13} \mathrm{C}$ and DEPT spectra were recorded on a Bruker AMX300 spectrometer operating at $75.468 \mathrm{MHz}$ equipped with a $5 \mathrm{~mm}$ QNP probe at room temperature. The EO $(150 \mathrm{mg})$ was dissolved in deuterochloroform $(0.5 \mathrm{ml})$, with all chemical shift values $(\delta)$ refer to tetramethylsilane (TMS) as internal standard and are given in ppm. ${ }^{13} \mathrm{C}$-NMR spectra were recorded with the following parameters: spectral width of $27777 \mathrm{~Hz}$ under low-power proton decoupling and ${ }^{13} \mathrm{C}$ pulse width of $7.5 \mu \mathrm{s}, 45^{\circ}$ excitation pulse, $2 \mathrm{~s}$ relaxation delay (D1) between scans, acquisition time of $3.867 \mathrm{~s}$, line broadening of 1.0 $\mathrm{Hz}$, for $64 \mathrm{~K}$ data table. The number of accumulated scans was $1 \mathrm{~K}(1024)$ and the plot limits +230 to $-6 \mathrm{ppm}$. Chemical shifts and peaks attribution of ${ }^{13} \mathrm{C}$-NMR spectra were made according to those in the literature ${ }^{12}$ and carvone and limonene standards. Multiplicities were obtained by 45,90 , and $135^{\circ}$ DEPT experiments while relative intensity was determined as relative percentage of NMR peak height.

\section{Screening for antimicrobial activity}

All microorganism strains were obtained from the Culture Collection of Industrial Microorganisms (CCMI) Laboratório de Microbiologia Industrial, Lisbon, Portugal. Bacteria: Escherichia coli CCMI 270, Listeria monocytogenes CCMI 1106 Micrococcus luteus CCMI 322, Pseudomonas aeruginosa CCMI 331, Streptococcus faecium CCMI 338, Staphylococcus aureus CCMI 335 , Streptococcus faecium CCMI 338 were used in a quantitative bioassay. Brain Heart Infusion (Merck, Darmstadt, Germany) was used as culture medium. The temperature and incubation time were $37^{\circ} \mathrm{C}$ at $24 \mathrm{~h}$, except for $M$. luteus which was incubated at $30^{\circ} \mathrm{C}$ for $48 \mathrm{~h}$. The antimicrobial activity of essential oil was determined by the broth dilution method ${ }^{13}$. The following concentrations were tested: $200,100,50,25$, and $12.5 \mu \mathrm{g} / \mathrm{ml}$. After incubation the microbial growth was examined. The results are expressed in Minimal Inhibitory Concentration (MIC), the weakest concentration of essential oil yielding no visible growth. The bactericidal/bacteriostatic activity was determined by a sub-cultivation of the samples in normal culture media at appropriate temperature and incubation times. The MIC of each compound was determined at least twice. The essential oil was dissolved in dimethylsulphoxide (DMSO) (Merck, Darmstadt, Germany).

\section{Antioxidant activity}

Green $\mathrm{ABTS}^{++}$radicals were generated by oxidizing $7 \mathrm{mM}$ aqueous solution of colorless ABTS [2,2'-azinobis(3-ethylbenzothiazoline-6-sulphonic acid)] with $2.45 \mathrm{mM}$ potassium persulfate and allowing the mixture to stand in the dark at room temperature for 12-16 h before use. Radical scavenging capacity was measured against $\mathrm{ABTS}^{++}$using $10 \mu \mathrm{l}$ of oil samples or Trolox diluted with $900 \mu 1$ of $\mathrm{ABTS}^{++}$solution, and the absorbance reading was taken 1 min after initial mixing at $734 \mathrm{~nm}$. The results were calculated using a standard curve prepared with Trolox and expressed as $\mathrm{mM}$ of Trolox equivalents per $\mathrm{Kg}$ of essential oil of L. camara.

\section{5-Lipoxygenase assay}

The assay mixture contained $10 \mu \mathrm{l}$ of oil dissolved in DMSO and Tween $20,0.1 \mathrm{M}$ potassium phosphate buffer $(\mathrm{pH} 6.3,2.95 \mathrm{ml})$ and $100 \mu \mathrm{M}$ linololeic acid. The reaction is initiated with the addition of $100 \mathrm{U} 5$-lipoxygenase diluted with phosphate buffer kept at $4^{\circ} \mathrm{C}$. The increase in absorbance at $234 \mathrm{~nm}$ was recorded for $10 \mathrm{~min}$. The percentage inhibition of enzyme activity was calculated by comparison with the negative control constituted by DMSO and Tween 20 . The percentage of enzyme activity was plotted against concentration of the oil. The $\mathrm{IC}_{50}$ value is the concentration of the L. camara oil that caused $50 \%$ enzyme inhibition. Nordihydroguaiaretic acid (NDGA) represented the positive control.

\section{RESULTS AND DISCUSSION}

The results of the GC and GC-MS analyses are listed in Table 2. Identification of the components was based on the comparison of the $\mathrm{GC}$ retention indices (RI) on polar and non-polar columns, determined relative to the retention time of a series of $n$-alkanes with linear interpolation with those of standards and with our essential oils database. The GC analysis of these EO showed that carvone is the most abundant monoterpene $75.9 \%$, together with limonene $16.9 \%$ making up $92.8 \%$ of the total oil. Peru oil also contains traces of sabinene, $p$-cymene, terpinene, $\beta$-caryophyllene and germacrene $\mathrm{D}$. The presence of the two major components was confirmed by MS, ${ }^{13} \mathrm{C}$ and DEPT NMR analysis (Table 3). The chemical shift values of the all carbons were compared with those reported for other oils ${ }^{12}$ and with carvone and limonene standards. ${ }^{13} \mathrm{C}-\mathrm{NMR}$ provided qualitative information on the total oil content of $L$. camara aerial parts. 
Table 2. Percentage composition of essential oil components identified in Lantana camara collected in Trujillo, Peru.

\begin{tabular}{|l|c|c|c|}
\hline \multicolumn{1}{|c|}{ Compound } & RI $^{1}$ & $\begin{array}{c}\text { Relative content } \\
\text { (\%) }\end{array}$ & $\begin{array}{c}\text { Mode of } \\
\text { identification }\end{array}$ \\
\hline$\alpha$-Thujene & 916 & 0.4 & RI, MS \\
\hline$\alpha$-Pinene & 925 & 0.1 & RI, MS \\
\hline Camphene & 941 & 0.1 & RI, MS \\
\hline Sabinene & 964 & 0.2 & RI, MS \\
\hline Myrcene & 979 & 0.4 & RI, MS \\
\hline$\alpha$-Phellandrene & 1000 & 0.1 & RI, MS \\
\hline$p$-Cymene & 1014 & 0.2 & RI, MS \\
\hline Limonene & 1025 & 16.9 & RI, MS, NMR \\
\hline cis-Ocimene & 1028 & 0.6 & RI, MS \\
\hline trans-Ocimene & 1037 & 0.1 & RI, MS \\
\hline Linalool & 1081 & 0.7 & RI, MS \\
\hline cis-Limonene oxide & 1118 & 0.1 & RI, MS \\
\hline Menthone & 1136 & 0.2 & RI, MS \\
\hline Isomenthone & 1153 & 0.2 & RI, MS \\
\hline cis-Dihydrocarvone & 1175 & 0.1 & RI, MS \\
\hline trans-Dihydrocarvone & 1182 & 0.2 & RI, MS \\
\hline trans-Carveol & 1206 & 0.2 & RI, MS \\
\hline Carvone & 1228 & 75.9 & RI, MS, NMR \\
\hline Piperitone & 1235 & 0.8 & RI, MS \\
\hline Carvone oxide & 1251 & 0.3 & RI, MS \\
\hline Piperitenone & 1317 & 0.5 & RI, MS \\
\hline$\beta$-Bourbonene & 1391 & 0.5 & RI, MS \\
\hline$\beta$-Elemene & 1394 & 0.2 & RI, MS \\
\hline$\beta$-Caryophyllene & 1426 & 0.1 & RI, MS \\
\hline Germacrene D & 1486 & 0.9 & RI, MS \\
\hline Nerolidol & 1546 & 0.1 & RI, MS \\
\hline
\end{tabular}

${ }^{1}$ Retention Indices identical to bibliography calculated through Kovats Indices on the OV-101 column.

Table 3. Spectral assignments of main monoterpenes detected in ${ }^{13} \mathrm{C}-\mathrm{NMR}$ spectrum of Lantana camara essential oil

\begin{tabular}{|c|c|c|c|c|c|}
\hline Peak & Compound & $\begin{array}{l}\delta \\
(\mathrm{ppm})\end{array}$ & $\begin{array}{l}\% \\
\text { Intensity }\end{array}$ & $\begin{array}{l}\text { Assig- } \\
\text { nment }\end{array}$ & \\
\hline 1 & Carvone & 15.29 & 79.8 & $\mathrm{CH}_{3}(\mathrm{C}-7)$ & \\
\hline 2 & Carvone & 20.09 & 74.9 & $\mathrm{CH}_{3}(\mathrm{C}-10)$ & \\
\hline 3 & Limonene & 20.40 & 15.9 & $\mathrm{CH}_{3}(\mathrm{C}-10)$ & \\
\hline 4 & Limonene & 23.08 & 17.8 & $\mathrm{CH}_{3}(\mathrm{C}-7)$ & \multirow{9}{*}{ Carvone } \\
\hline 5 & Limonene & 27.50 & 20.5 & $\mathrm{CH}_{2}(\mathrm{C}-3)$ & \\
\hline 6 & Limonene & 30.18 & 19.2 & $\mathrm{CH}_{2}(\mathrm{C}-5)$ & \\
\hline 7 & Limonene & 30.40 & 19.9 & $\mathrm{CH}_{2}(\mathrm{C}-2)$ & \\
\hline 8 & Carvone & 30.89 & 97.6 & $\mathrm{CH}_{2}(\mathrm{C}-5)$ & \\
\hline 9 & Limonene & 40.66 & 15.9 & $\mathrm{CH}(\mathrm{C}-4)$ & \\
\hline 10 & Carvone & 42.08 & 100.0 & $\mathrm{CH}(\mathrm{C}-4)$ & \\
\hline 11 & Carvone & 42.71 & 85.6 & $\mathrm{CH}_{2}(\mathrm{C}-3)$ & \\
\hline 12 & Limonene & 108.05 & 22.8 & $\mathrm{CH}_{2}(\mathrm{C}-9)$ & \\
\hline 13 & Carvone & 110.07 & 94.0 & $\mathrm{CH}_{2}(\mathrm{C}-9)$ & \\
\hline 14 & Limonene & 120.26 & 13.5 & $\mathrm{C}=\mathrm{C}(\mathrm{C}-6)$ & \\
\hline 15 & Limonene & 132.90 & 2.0 & $\mathrm{C}=\mathrm{C}(\mathrm{C}-1)$ & \\
\hline 16 & Carvone & 134.94 & 22.3 & $\mathrm{C}=\mathrm{C}(\mathrm{C}-1)$ & \\
\hline 17 & Carvone & 144.20 & 53.9 & $\mathrm{CH}(\mathrm{C}-6)$ & \\
\hline 18 & Carvone & 146.21 & 28.8 & $\mathrm{C}=\mathrm{C}(\mathrm{C}-8)$ & \\
\hline 19 & Limonene & 149.00 & $t$. & $\mathrm{C}=\mathrm{C}(\mathrm{C}-8)$ & \\
\hline 20 & Carvone & 199.09 & 7.93 & $\mathrm{C}=\mathrm{O}(\mathrm{C}-2)$ & \\
\hline
\end{tabular}

Antibacterial activity of $L$. camara $\mathrm{EO}$ was evaluated against the human pathogens E. coli, P. aeruginosa, S. aureus, S. faecium and the food spoilages $M$. luteus and L. monocytogenes. The EO inhibited the growth of $S$. aureus with bacteriostatic activity at $200 \mu \mathrm{g} / \mathrm{ml}$ but did not exhibit any antibacterial activity against other microorganisms tested (MIC were $>200 \mu \mathrm{g} / \mathrm{ml}$ ). Some authors $^{5}$ reported the activity of $L$. camara oil from India against $S$. aureus, E. coli, and $P$. aeruginosa. Peru oil did not show activity against the last two microorganisms, but the results are not comparable because the methodologies used and the chemical composition of the oils is different. The antibacterial activity may be related to the chemical proportion of the main compounds, carvone and limonene, as well to the minor components present in our EO. Some authors ${ }^{14}$ detected that isolated $(R)-(+)$-isomers of limonene and carvone appeared to be much more potent against a range of bacteria when compared to the essential oils where they occur. However, these authors also observed that corresponding (S)-(-)-isomers may exhibit different activities which could be due to the synergism of the minor components present in EOs. Indeed, chemically the EOs are quite complex mixtures of a large variety of constituents, and theirs antimicrobial activity can be attributed to several active compounds as well as to the synergetic effects between them and to the different proportions in which they are present in the mixtures. Thus, this complexity makes it often difficult to explain the activities.

Several assays have been frequently used to estimate antioxidant capacities in essential oils, including 2,2'-azinobis(3-ethylbenzothiazoline-6-sulphonic acid) (ABTS $)^{15,16}$. This method is based on the ability of antioxidants to quench the ABTS radical cation relative to that of Trolox (water-soluble vitamin $\mathrm{E}$ analogue). The activity found for L. camara was $29.0 \mathrm{mmol}$ Trolox $/ \mathrm{kg}$. This value is similar to that obtained by some authors ${ }^{16}$ for Origanum vulgare L. oil $(25.1 \mathrm{mmol}$ Trolox $/ \mathrm{kg})$ and higher than that of Lippia alba Mill. oil (14.4 mmol Trolox $/ \mathrm{kg}$ ) in which carvacrol and carvone predominated in the respective oils. The authors attributed the antioxidant activity of $O$. vulgare oil to the relatively large amount of carvacrol, but in the same work other essential oils also showed values close to that observed for oregano oil, and they were constituted by trans-anethole (Pimpinella anisum L.) $(24.3 \mathrm{mmol}$ Trolox/kg), ledol (Lepechinia schiedeana) $(25.7 \mathrm{mmol}$ Trolox $/ \mathrm{kg})$, and linalool (Cananga odorata) $(38.6 \mathrm{mmol}$ Trolox $/ \mathrm{kg}$ ). Comparing these results with ours, we can consider that the carvone-rich oil of $L$. camara from Peru possesses a particularly high antioxidant capacity. Such results may be partially explained by the presence of carvone, a $\alpha, \beta$-unsaturated ketone, which is more active than ketone monoterpenes according some authors ${ }^{17}$. Until now, only extracts of $L$. camara from Bolivia were reported as good antioxidants when evaluated by two other methods: $\beta$-carotene bleaching technique and DPPH free radical technique.

Inflammation is a normal pathophysiological response to the attack of infectious agents or to physical, chemical or traumatic injuries. The mechanism of inflammation involves complex cascades of events in which the pro-inflammatory leukotrienes, resulting from the metabolism of arachidonic acid have an important role. The enzyme 5-lipoxygenase, which promotes the oxidation of arachidonic acid, is involved in the formation of this class of messengers ${ }^{18}$. The concentration of $L$. camara oil that produced a $50 \%$ inhibition $\left(\mathrm{IC}_{50}\right)$ of lipoxygenase was $81.5 \mu \mathrm{g} / \mathrm{ml}$, not as good as the positive control $(49.5 \mu \mathrm{g} / \mathrm{ml})$. According to an arbitrary relative in vitro anti-inflammatory activity scale established by Baylac and Racine ${ }^{18}$, we can consider that the L. camara oil from Peru possesses a weak activity $\left(51<\mathrm{IC}_{50} £ 100 \mathrm{mg} \mathrm{L} / 1\right)$ when assessed by this method. Extracts of L. camara have revealed antiinflammatory activities ${ }^{9,11}$, but such results cannot be directly compared to ours since the methods used for anti-inflammatory evaluations were quite different. Some authors ${ }^{10}$ also reported anti-inflammatory activity in extracts of $L$. camara in which saponins, tannins and flavonoids were present. The anti-inflammatory activity of $L$. camara has been attributed to the presence of the pentacyclic triterpenes, oleanolic acid, and ursolic acid, which act as inhibitors of human leucocyte elastase as well as COX-2 (cyclooxigenase isoenzyme $)^{2}$. The high antioxidant activity of $L$. camara oil from Peru, evaluated by the Trolox equivalent antioxidant capacity assay (TEAC) was observed $(29.0 \mathrm{mmol}$ Trolox $/ \mathrm{kg})$. We suggest that this effect may be related to the presence of carvone and limonene, which are the major components the EO from L. camara $(92.8 \%)$ and also considerable antioxidants. Since carvone had not yet been identified in L. camara oils (see Table 1) the Peru oil seems to be a new chemotype, which may be confirmed through the chemical composition analysis of plants recollected in different Peru regions and seasons in order to compare the chemical evolution of the main constituents. 


\section{ACKNOWLEDGEMENTS}

We acknowledge with thanks the financial support of the Dirección de Investigación, Universidad Arturo Prat in Chile, and Departamento de Tecnologia de Indústrias Químicas-INETI and Centro de Desenvolvimento de Ciências e Técnicas de Produção Vegetal (CDCTPV), in Portugal.

\section{REFERENCES}

1. A. Brick, Diccionario Enciclopédico de Plantas útiles del Perú. Programa de las Naciones Unidas para el Desarrollo. Centro de Estudios Regionales Andinos "Bartolomé de Las Casas" Cusco, Perú, 1999.

2. E. L. Ghisalberti. Fitoterapia. 71, 467, (2000).

3. O. P. Sharma, Vet. Hum. Toxicol. 26, 488, (1984).

4. O. P. Sharma, H. P. S. Makkar, R. K. Dawra, S. S. Negi, Toxicon. 26, 975, (1988).

5. M. J. Deena, J. E. Thoppil, Fitoterapia. 71, 453, (2000).

6. A. J. Sundufu, H. Shoushan, Flavour. Fragr. J. 19, 229, (2004).

7. G. Alitonou, F. Avlessi, I. Bokossa, E. Ahoussi, J. Dangou, D. C. K Sohounhloué, C.R. Chim. 7, 1101, (2004).

8. A. Rosas-Romero, G. Saavedra, Pharm. Biol. 43, 79, (2005).

9. A. M. Forestieri, M. T. Monforte, S. Ragusa, A. Trovato, Phytother. Res. 10, 100, (1996).

10. O. O. Oyedapo, F. C. Sab, J. A. Olagunju, Biomed. Lett. 59, 175, (1999).

11. S. Basu, B. Hazra, Phytother. Res. 20, 896, (2006).

12. K.-H. Kubeczka, V. Formáček, Essential Oils Analysis by Capillary Gas Chromatography and Carbon-13 NMR Spectroscopy, 2nd Edition, John Wiley \& Sons, Ltd, England, 2002.
13. P. A. Wayne, Performance standards for antimicrobial susceptibility testing. Ninth informational supplement NCCLS document M100-S9. National Committee for Clinical Laboratory Standards, 2008.

14. K. K. Aggarwal, S. P. S. Khanuja, A. Ahmad, T. R. Santha Kumar, V. K. Gupta, S. Kumar, Flavour Fragr. J. 17: 59, (2002).

15. D. Mantle, J. G. Anderton, G. Falkous, M. Barnes, P. Jones, E. K. Perry, Comp. Biochem. Physiol. (Part B). 121, 385, (1998).

16. M. Puertas-Mejía, S. Hillebrand, E. Stashenko, P. Winterhalter, Flavour. Fragr. J. 17, 380, (2002).

17. G. Ruberto, M. T. Baratta, Food Chem. 69, 167, (2000).

18. S. Baylac, P. Racine, Int. J. Aromather. 23, 138, (2003).

19. M. B. Ngassoum, S. Yonkeu, L. Jirovetz, G. Buchbauer, G. Schmaus, F. J. Hammerschmidt, Flavour Fragr. J. 14, 245, (1999).

20. S. Mollenbeck, T. Konig, P. Schreier, W. Schwab, J. Rajaonarivony, L. Ranarivelo, Flavour Fragr. J. 12, 63, (1997).

21. J.-A. Randrianalijaona, P. Ramanoelina, J. Rasoarahona, E. Gaydou, Anal. Chim. Acta. 545, 46, (2005).

22. J.-M. Ouamba, A. Ouabonzi, A. Ekouya, J.-M. Bessière, C. Menut, A. A. Abena, J.-T. Banzouzi, Flavour Fragr. J. 21, 158, (2006).

23. P. Weyerstahl, H. Marschall, A. Eckhardt, C. Christiansen, Flavour. Fragr. J. 14, 15, (1999).

24. M. H. da Silva, E. H. Andrade, M. G. Zoghbi, A. I. Luz, J. D. Silva, J. G. Maia, Flavour Fragr. J. 14, 208, (1999).

25. E. E. Stasbenko, B. F. Jaramillo, J. R. Matinez, Rev. Acad. Coloma Cienc. 27, 579, (2003).

26. F. Sefidkon, Flavour Fragr. J. 17, 78, (2002).

27. M. Khan, S. K. Srivastava, K. V. Syamasundar, M. Singh, A. A. Naqvi, Flavour Fragr. J. 17, 75, (2002).

28. M. M. Fathy, Bull. Fac. Pharm. Cairo Univ. 38, 105, (2000). 